\title{
Host Suitability of Weeds to the Root Lesions Nematoid in Soybean Areas in the North of Goias, Brazil
}

\author{
Rafael M. da Silva ${ }^{1}$, Anderli D. F. Rios ${ }^{2}$, Denise R. Conceição ${ }^{3}$, Wilian H. D. Buso ${ }^{4}$, Alan S. Machado ${ }^{4}$, \\ Grasiele T. da Silva ${ }^{3}$, Matheus V. A. Ventura ${ }^{5}$, Emizael M. de Almeida ${ }^{6}$, Hellismar W. da Silva ${ }^{7}$, \\ Kenia L. Trindade ${ }^{1} \&$ Estevam M. Costa ${ }^{5}$ \\ ${ }^{1}$ Postgraduate Program in Irrigation in the Cerrado, Goiano Federal Institute, Ceres, Brazil \\ ${ }^{2}$ Postgraduate Program in Agronomy, Goias Federal University, Goiania, Brazil \\ ${ }^{3}$ School of Agronomy, Evangelical Faculty of Goianesia, Goianesia, Brazil \\ ${ }^{4}$ Postgraduate Program in Animal Science, Goias Federal University, Goiania, Brazil \\ ${ }^{5}$ Postgraduate Program in Agrarian Sciences-Agronomy, Goiano Federal Institute, Rio Verde, Brazil \\ ${ }^{6}$ Postgraduate Program in Zootechny, Goias Federal University, Goiania, Brazil \\ ${ }^{7}$ Postgraduate Program in Agronomy/Plant Science, Federal University of Lavras, Lavras, Brazil \\ Correspondence: Rafael Matias da Silva, Postgraduate Program in Irrigation in the Cerrado, Goiano Federal \\ Institute, Ceres, Brazil. Tel: 55-62-98437-0774. E-mail: rafael.gsia10@gmail.com
}

Received: October 24, 2018

doi:10.5539/jas.v11n4p485

\author{
Accepted: January 13, 2019 Online Published: March 15, 2019 \\ URL: https://doi.org/10.5539/jas.v11n4p485
}

\begin{abstract}
Several studies have done more on weed and nematode hosts. It is important to know a host of weeds and $P$. brachyurus in areas cultivated with soy. This nematode can stay in weed roots even in the absence of plants grown in the off-season, making it difficult to control them. The objective was to evaluate the host suitability of emerged weed species in cultivated areas with a soybean crop to the P. brachyurus nematode under natural infestation conditions. The surveys were conducted in commercial properties located in the municipalities of Campinorte and Rialma, both in the northern region of the state of Goias, Brazil under the no-tillage and conventional system, respectively, with a history of high nematode population densities. We evaluated 19 weed species with the highest expressivity in the properties. The population densities of the nematode ranged RFom 23 to 17,113 and 55 to 4,221 specimens per 10 grams of roots respectively. All as weed species evaluated as hosts of P. brachyurus. As species, Hyptis suaveolens, Sida cardifolia, Senna occidentalis, Coneyza canadensis and Commelina benghalensis had low population densities.
\end{abstract}

Keywords: population density, Pratylenchus brachyurus, soybean

\section{Introduction}

The genus Pratylenchus is the second most important group of phytonematoids in the world, being surpassed only by the genus Meloidogyne (Tihohod, 1993). In Brazil, the species Pratylenchus brachyurus and Pratylenchus zeae have increased their importance due to reports of their occurrence in important crops such as soybeans and corn mainly in the center-west of Brazil (Dias et al., 2010). The Central West region, the largest grain producer in Brazil (Conab, 2018), faces the occurrence of this nematode at high levels in some crops. Sharma (1996) reported the high occurrence of P. brachyurus (31,970 specimens per 10 grams of roots) in soybean in the late 1980s (1988/1989 harvest), in Ipameri, Goiás. At the time, there was a 41\% reduction in grain yield in the area affected by the nematode. Several studies have been carried out to evaluate the effect of the nematode (Rios et al., 2016; Lima et al., 2011; Alves et al., 2011; Inomoto, 2011). The greater occurrence of this nematode was favored, mainly, by changes in the production system, such as intensification of no-tillage, irrigation use and succession use with host crops. In this way, the area remains with plants or roots allowing nematode survival throughout the year (Goulart, 2008).

The control of $P$. brachyurus nematoide in soybean areas is complex. The main control measures for nematodes in general, such as the succession of crops, can be difficult, since this nematode has a polyphagous habit. In the Central-West region of Brazil, the most commonly used crops are sorghum (Sorghum bicolor (L.) Moench), 
Milheto (Pennisetum glaucum (L.) R. Brown) and Corn (Zea mays L.) is the main crop used in succession in soybean areas, but it promotes an increase in the population density of $P$. brachyurus, as it is highly susceptible to the nematode (Embrapa, 2013; Inomoto et al., 2011). Chemical control is costly and ineffective, and genetic resistance to P. brachyurus is still incipient. Another measure of control is the use of fallow (without planting crops) in the off season, this measure may be important to reduce the population density of the nematode in the area. However, in some cases the fallow time is difficult to adopt by the farmer because it leaves the area unproductive for some months and also the presence of some host weeds of this nematode remain alive in the area keeping the nematodes alive (Ferraz et al., 2010).

The host of weeds and nematodes are known. These nematodes can stay in the roots of weeds in the off season or even during the harvest, increasing their population density. Most of these studies are with nematodes in the genus Meloidogyne and under controlled greenhouse conditions.

Asmus and Andrade (1997) carried out studies to verify the host suitability of weeds to M. javanica under controlled greenhouse conditions. In this study, the reproductive factor ((ratio between the final population (FP) and the initial population (IP)), according to Oostenbrink (1966) When the reproductive factor (FR) is $\leq 1$, the host plant is considered resistant to the nematode, while when the RF found is $>1$, the plant is considered susceptible or host of the nematode.

Samaliev and Kalinova (2013) also studied the host suitability of weeds to nematodes. The weeds were hosts of the nematodes Pratylenchus penetrans and Meloidogyne hapla, the RF ranged from 0.17 to 4.9 for P. penetrans and from 0.22 to 5.5 for M. hapla in studies conducted under greenhouse conditions. Thus, these studies prove the host suitability of weeds to nematodes.

With regard to species $P$. brachyurus, few studies were carried out to evaluate the host suitability of weed species to this nematode in soybean areas, especially under natural conditions. One of the studies was carried out by Fuhrmann et al. (2009) who evaluated the host suitability of weeds the P. brachyurus in greenhouse conditions, in the study observed the susceptibility of the weed specie Eleusine indica to the nematode. In another study, Belle et al. (2015) in greenhouse work also reported the susceptibility of Eleusine indica to P. brachyurus. The population density was high, with about 8083 individuals, thus acting as a good host for the P. brachyurus. In light of this information, we aimed to evaluate the host suitability of weed species to the nematode $P$. brachyurus under field condition.

\section{Method}

Two surveys were carried out to verify the host suitability of weeds to the root lesions nematoid, P. brachyurus. The surveys were carried out on commercial soybean farms with nematode reporter histories. The first survey was carried out in Campinorte and the second in Rialma, both in the northern region of the State of Goias, Brazil.

\subsection{Survey 01}

The study area consisted of $2700 \mathrm{~m}^{2}$ and was delimited according to the history of reforestation in the previous crop of the soybean crop. In the area, the planting system adopted was no-tillage.

The study area was left fallow between April and November 2012. On December 1, 2012, the herbicide glyphosate $\left(648 \mathrm{~g}\right.$ i.a. $\left.\mathrm{L}^{-1}\right)$ with the help of a tractor sprayer, this operation was performed only once during the pre-emergence, then the delimited area was sealed and the weeds were allowed to emerge. In this delimited and fenced area was sown to soybean cultivar BRSGO Caiapônia and corn hybrid AG 1051 in pits with six replicates and were used as controls.

On February 15, 2013, five plants of the same species were randomly collected, totaling five replicates of each weed species. All weeds collected (Table 1) were in flowering, samples were collected the same day. 
Table 1. Weeds and witnesses collected in a naturally infested area. Campinorte, Goiás, 2013

\begin{tabular}{lll}
\hline Common name & Scientific name & Family \\
\hline Capim favorito & Rhynchelitrum repens (Willd.) C.E. Hubb & Poaceae \\
Capim arroz & Echinochloa crus-pavonis (Kunth) Hitchc & Poaceae \\
Capim amargoso & Digitaria insularis (L.) Fedde & Poaceae \\
Capim-pé-de-galinha & Eleusine indica (L.) Gaertn & Poaceae \\
Capim barbicha & Eragrostis maypurensis (Kunth) Steud. & Poaceae \\
Capim raposa & Setaria parviflora (Poir.) Kerguélen & Poaceae \\
Cheirosa & Hyptis suaveolens (L.) Point. & Lamiaceae \\
Malva branca & Sida cordifolia L. & Malvaceae \\
Fedegoso & Senna obtusifolia (L.) H.S. Irwin \& Barneby & Fabaceae \\
Buva & Conyza canadensis (L.) Cronquist & Asteraceae \\
Soja (BRSGO Caiapônia) $*$ & Glycine max & Fabaceae \\
Milho (AG 1051) $*$ & Zea mays & Poaceae \\
\hline
\end{tabular}

Note. * Growing of soybean and corn hybrid used as witnesses.

For the ten weed species evaluated, six samples were collected randomly at different locations and within the demarcated area for survey, thus totaling 72 samples in the area. The soy and corn roots were collected 60 days after sowing.

For the collection of samples, the opening of a pit with approximately $10 \mathrm{~cm}$ of width and $15 \mathrm{~cm}$ of depth was performed and the plants were removed. All weeds were collected and the roots of soybean and corn were packed properly in identified plastic bags and taken to the laboratory of the department of agriculture and animal husbandry of the Goiano Federal Institute campus Ceres, in Ceres-Goias, Brazil.

In the laboratory, the weeds were identified and the aerial part of the plants, including those of soybeans and corn were discarded and the roots were submitted to nematoid extraction, where they were weighed, and crushed for 30 seconds with the aid of a blender, and then the samples were taken to centrifuge, first in solution with water and kaolin, and then with sucrose according to methodology described by Coolen and D'Herde (1972).

The identification and quantification of the phytonematoids were performed with the aid of an optical microscope using a Peters chamber. The identification of the phytonematoid species was carried out through the morphological characteristics, where in each experimental site this identification was performed in ten samples. The species P. brachyurus was the species of phytonematoids found in $100 \%$ of the separate samples. Data were submitted to analysis of variance, using the statistical program SASM Agri. The means were compared using the Scott-Knott test at $5 \%$ probability. The data were transformed into $\log \mathrm{x}$ to perform the statistical analyzes according to Box and Cox (1964).

\subsection{Survey 02}

The total area used for this survey was approximately $3000 \mathrm{~m}^{2}$ and was delimited as a function of the history of reeds in the previous crop of soybean and corn. The study area was left fallow in the off season (period between August and November).

At the beginning of the rains, in November 2016 the herbicide glyphosate $\left(648 \mathrm{~g}\right.$ i.a. $\left.\mathrm{L}^{-11}\right)$ was applied with the aid of a tractor sprayer. The ten weed species were collected in January 2017. The species were chosen because they had the highest occurance in the area and were emerged together with the soybean crop in the delimited area.

The weed species (Table 2) were collected by collecting five plants of the same species randomly into the separate area for the survey, with five replicates. The plants were collected through a pit opening approximately $10 \mathrm{~cm}$ wide and $15 \mathrm{~cm}$ deep and the plants.

The weeds were collected on the same day and at the initial flowering stage. All the weeds collected were identified and soon afterwards the root was discarded and the roots were packed in plastic bags, properly identified and taken to the Evangelical Faculty of Goianesia, Goianesia-Goias, Brazil. 
Table 2. Weeds and witnesses collected in a naturally infested area. Rialma, Goiás, 2017

\begin{tabular}{lll}
\hline Common name & Scientific name & Family \\
\hline Leiteira & Euphorbia heterophylla L. & Euphorbiaceae \\
Capim gordura & Melinis minutiflora P. Beauv. & Poaceae \\
Timbete & Cechrus echinatus L. & Poaceae \\
Capim massambará & Sorghum halepense L. Pers. & Poaceae \\
Capim colonião & Panicum maximum Jacq. & Poaceae \\
Joá-de-capote & Nicandra physaloides (L.) Gaertn. & Solanaceae \\
Caruru & Amaranthus lividus L. & Amaranthaceae \\
Quebra pedra & Chamaesyce prostrata (Ailton) Small & Euphorbiaceae \\
Capim-pé-de-galinha & Eleusine indica (L.) Gaertn & Poaceae \\
Trapoeraba & Commelina benghalensis L. & Commilinaceae \\
\hline
\end{tabular}

In the laboratory the roots were submitted for nematode extraction and the identification of the specimen was performed according to survey 1 . The data were submitted to analysis of variance, using the statistical program SASM Agri. The means were compared using the Scott-Knott test at $5 \%$ probability. The data were transformed into $\sqrt{\mathrm{X}+0}$ for statistical analysis according to the Box and Cox (1964).

\section{Results}

In both surveys the weeds hosted the nematoid P. brachyurus. In the first survey (Table 3 ) the population density varied from 23.6 to 17.113 nematodes per 10 grams of roots and in the second survey (Table 4) the population density of the nematode ranged from 55.4 to 4.122 nematodes per 10 grams of roots.

Jordaan and Waele (1988) also verified this variation of hostability between weed and nematode species of the genus Pratylenchus, species $P$. zeae. The nematode population density variation among common weed species in maize areas in South Africa was 591 to 2068 specimens per 5 grams of roots in works under controlled greenhouse conditions.

\subsection{Survey 01}

In the first study (Table 3), the statistical analysis $(\mathrm{P}<0.05)$ separated the weeds into five groups of different hosts according to the population density of the nematode P. brachyurus in the roots (specimens of $P$. brachyurus per ten grams of roots).

Table 3. Population density (PD) of Pratylenchus brachyurus in weeds in a naturally infested area. Campinorte, Goias, 2013

\begin{tabular}{|c|c|c|}
\hline Weeds & Family & PD in P. brachyurus $/ 10 \mathrm{~g}$ in root \\
\hline Capim favorito & Poaceae & $17.113 \mathrm{a}$ \\
\hline Capim arroz & Poaceae & $3.823 \quad b$ \\
\hline Capim amargoso & Poaceae & $3.543 \quad b$ \\
\hline Capim-pé-de-galinha & Poaceae & $2.166 \mathrm{c}$ \\
\hline Capim barbicha & Poaceae & $1.910 \mathrm{c}$ \\
\hline Capim raposa & Poaceae & 565 \\
\hline Cheirosa & Lamiaceae & 31 \\
\hline Malva branca & Malvaceae & 23 \\
\hline Fedegoso & Fabaceae & 27 \\
\hline Buva & Asteraceae & 23 \\
\hline Soja (BRSGO Caiapônia) & Fabaceae & 27 \\
\hline Milho (AG 1051) & Poaceae & 23 \\
\hline $\mathrm{CV}(\%)$ & & 9.65 \\
\hline
\end{tabular}

Note. Means followed by the same letter do not differ by Scott-Knott's test at 5\% probability. Data transformed into $\log (\mathrm{x})$. 


\subsection{Survey 02}

In the second study (Table 4), the statistical analysis $(\mathrm{P}<0.05)$ separated the weed species into four groups according to the degree of susceptability according to the population density of the nematode $P$. brachyurus in the roots (specimens of $P$. brachyurus per ten grams of roots).

Table 4. Population density (PD) of Pratylenchus brachyurus in weeds in naturally infested area. Rialma, Goiás, 2017

\begin{tabular}{lll}
\hline Weeds & Family & PD in P. brachyurus/10 gin root \\
\hline Leiteira & Euphorbiaceae & $4.221 \mathrm{a}$ \\
Capim gordura & Poaceae & $3.424 \mathrm{a}$ \\
Timbete & Poaceae & $3.123 \mathrm{a}$ \\
Capim massambará & Poaceae & $2.139 \mathrm{~b}$ \\
Capim colonião & Poaceae & $1.671 \mathrm{~b}$ \\
Joá-de-capote & Solanaceae & $1.586 \mathrm{~b}$ \\
Caruru & Amaranthaceae & $999 \mathrm{c}$ \\
Quebra pedra & Euphorbiaceae & $698 \mathrm{c}$ \\
Capim-pé-de-galinha & Poaceae & $483 \mathrm{c}$ \\
Trapoeraba & Commilinaceae & $55 \mathrm{~d}$ \\
CV $(\%)$ & & 19.36 \\
\hline
\end{tabular}

Note. Means followed by the same letter do not differ by Scott-Knott's test at 5\% probability. Data transformed into $\sqrt{\mathrm{x}+0}$.

\section{Discussion}

Several papers have been published with nematode weed host studies. In most cases, nematodes of the genus Meloidogyne (root-knot nematode), such as the studies by Roese and Oliveira (2004) and Monaco et al. (2008) hat demonstrated the host suitability of grass species rice to nematodes M. paranaensis and studies of Mônaco et al. (2009) and Cordeiro et al. (2014) demonstrated the susceptibility of the dairy species to Meloidogyne incognita, M. javanica and M. paranaensis.

The Sorghum halepense also was host of root-knot nematode in the work of Lordello et al. (1988) and Mônaco et al. (2009) under controlled greenhouse conditions. The species Nicandra physaloides and Amaranthus lividus were hosts of M. javanica and M. incógnita respectively (Hillocks et al., 1995; Ferraz, 1982).

In the present study, two surveys were carried out and a large variation in nematode susceptibility was observed $P$. brachyrurus among weed species collected. The favorite grass weed was highly susceptible host a large number of nematodes in its root system, presented the highest population density for the two surveys (17113 $P$. brachyurus per 10 grams of roots), larger than corn AG 1051 (6808 in P. brachyurus/10 grams of roots), used in the first survey as a host plant.

At weeds Echinochloa crus-pavoni, Digitaria insularis, Eleusine indica, Eragrostis maypurensis and Setaria parviflora all belonging to the family Poaceae were good hosts of the nematode. All these species were more susceptible than soybean (952 P. brachyurus/10 grams of roots) with the exception of Setaria parviflora whose population density was 565 specimens per ten grams of roots.

Samaliev and Kalinova (2013), also found susceptibility to nematode in the case of, P. penetrans and M. hapla which presented RF of 2.4 and 0.6 respectively in studies conducted under greenhouse controlled conditions.

The weed Eleusine indica was collected in both surveys and was host to P. brachyurus in both locations. The population density varied greatly from one survey to the other. The density per ten grams of roots was of 2,166 specimens in the first survey and 483 in the second survey. Probably the area of the first survey had a higher population density of the nematode in the area. Other studies show this behavior of weed Eleusine indica to nematodes. Jordaan and Waele (1988) found high population density for the nematode of the genus Pratylenchus, in this case, the species $P$. zeae in roots of Eleusine indica in corn fields in South Africa. The density was approximately 1000 specimens per five grams of roots.

Belle et al. (2017) also reported the multiplication of P. zeae at the Eleusine indica. The work was conducted in a greenhouse where the inoculation of 1000 individuals of P. zeae where evaluations were performed 90 days after 
inoculation. The RF found was 3.90, that is, greater than 1, and with a population density of 3,290 nematodes. Fuhrmann et al. (2009) evaluated the host suitability of weeds at $P$. brachyurus under greenhouse conditions and also observed host suitability of the species Eleusine indica to the nematodes. Belle et al. (2015) work done in a greenhouse also reported the ability to Eleusine indica. The population density was high, with about 8083 individuals, thus acting as a good host for the P. brachyurus. While, Braz et al. (2016) found resistance to the species Eleusine indica studies carried out in greenhouse with the inoculation of 1000 specimens of $P$. brachyurus per plant. The evaluation of RF was performed at 90 days after inoculation. In the study the species Sida cordifolia presented RF of 2.16 and more than 4.000 P. brachyurus per root system.

At weeds: Hyptis suaveolens, Sida cordifolia, Senna obtusifolia and Conyza canadensis presented low host suitability to P. brachyurus in this survey. To Senna obtusifolia, Braz et al. (2016) and Mônaco et al. (2008) found resistance to P. brachyurus and M. paranaensis respectively, while Fuhrmann et al. (2009) found susceptibility of this weed to $P$. brachyurus under greenhouse conditions.

For a species Euphorbia heterophylla, Melinis minutiflora and Cechruse chinatus, the population densities were the highest in the second survey and the statistical analysis separated these species in the group of the most susceptible plants of the study. These species were the ones that presented the highest population densities of $P$. brachyurus, showing, therefore, the weeds with greater capacity to harbor and multiply the nematoid in the present study. Fuhrmann et al. (2009) evaluating the susceptibility of some weed species to P. brachyurus in greenhouse observed the highest RF of the nematode was found for the species Euphorbia heterophylla.

Belle et al. (2017), also evaluated the host suitability of weeds to nematodes. In the study the evaluation of the reaction of 25 weed species to the nematoid $P$. zeae. 1,000 specimens of the nematode were inoculated per vessel The evaluation was performed at 90 days after inoculation and all weed species were good hosts of the nematode The RF found was greater than 1 for all 25 species evaluated with population density of 1034 to 6981 nematodes per pot. In this study, species Panicum maximum, Euphorbia heterophylla and Eleusine indica presented RF of 3.87, 2.45 and 3.29 respectively, being good hosts of $P$. zeae.

To Sorghum halepense and Cechrus echinatus, Belle et al. (2017) and Belle et al. (2015) reported their nematode host populations of the genus Pratylenchus in studies under greenhouse controlled conditions. In the first study they inoculated specimens of $P$. zeae in plants arranged in pots to evaluate the host suitability of these weeds to species $P$. zeae whose RF were 4.25 and 2.75 for Sorghum halepense and Cechrus echinatus respectively. In the second study they inoculated specimens of P. brachyurus and the RF were 6.9 and 9.2. Thus, these studies prove that weeds host and multiply nematodes of the genus Pratylenchus, mainly species $P$. brachyurus.

The Panicum maximum, Nicandra physaloides, Amaranthus lividus and Chamaesyce prostrata were also hosts of the nematode, but at lower population densities. Stirling et al. (2010) also found susceptibility of nematodes of the genus Pratylenchus, the species $P$. zeae in grass roots colonization in fields of sugar cane in Australia. The study was conducted under greenhouse conditions in the United Kingdom. About 600 nematodes were inoculated per pot and 70 days after inoculation the population density found was 3577 specimens.

The weed Commelina benghalensis presented low host suitability of P. brachyurus in the present study, presenting a population density of 55 specimens per 10 grams of roots. Braz et al. (2016) evaluated the host suitability of this weed to the nematode P. brachyurus in a greenhouse experiment. In this study a population of 2000 specimens per pot was inoculated. The RF was below 0 demonstrating resistance of Commelina benghalensis to $P$. brachyurus.

To observe all species of plants evaluated in the two surveys P. brachyurus, but the degree of host suitability is very variable for each evaluated species, showing differences in the host suitability or even the degree of pathogenicity among $P$. brachyurus populations at each site.

Among these species, the weeds of the family Poaceae stand out as great hosts of the nematode, whose population density reached 17113 specimens per 10 grams of roots. Inomoto et al. (2007) evaluated the reaction of Poaceae Panicum maximum and Brachiaria P. brachyurus. It was verified that the Poaceae evaluated were hosts of $P$. brachyurus in different degrees of infestation and should be avoided as cover crops in fields infested with this nematode.

In this way the control of weeds becomes relevant in a Pratylenchus management program due to its host suitability, which may have negative consequences for the cultivated areas where they are found, allowing the phytonematoid survival mainly in the off season.

All weeds collected in the surveys have housed P. brachyurus in varying degrees of susceptibility. The weed species of the family Poaceae and Euphorbiaceae evaluated had the highest population densities of the nematode. 


\section{References}

Alves, T. C. U., da Silva, R. A., Borges, D. C., Motta, L. C. C., \& Kobayasti, L. (2011). Reação de cultivares de soja ao nematoide das lesões radiculares Pratylenchus brachyurus. Biodiversidade, 10(1), 73-79.

Antonio, H., \& Lehman, P. S. (1978). Nota sobre a ocorrência de nematoides do gênero Meloidogyne em algumas ervas daninhas nos estados do Paraná e do Rio Grande do Sul. Reunião de Nematologia, 3(pp. 29-32). Mossoró, Anais.

Asmus, G. L., \& Andrade, P. J. M. (1997). Reprodução de Meloidogyne javanica em cultivares de milho. Nematologia Brasileira, 21(2), 39-47.

Bellé, C., Kaspary, T. E., Kuhn, P. R., Schmitt, J., \& Lima-Medina, I. (2017). Reproduction of Pratylenchus zeae on Weeds. Planta Daninha, 35, e017158528. https://doi.org/10.1590/s0100-83582017350100006

Belle, C., Lima-Medina, I., Kaspary, T. E., \& Kuhn, P. R. (2015). Capacidad hospedadora de plantas adventicias a Pratylenchus brachyurus en el noroeste de Rio Grande del Sur, Brasil. Nematropica, 45(2), 144-149.

Box, G. E., \& Cox, D. R. (1964). An analysis of transformations. Journal of the Royal Statistical Society. Series $B$ (Methodological), 26(2), 211-252. https://doi.org/10.1111/j.2517-6161.1964.tb00553.x

Brachtvogel, E. L. (2010). População de plantas e uso de piraclostrobina na cultura do milho: Alterações agronômicas e fisiológicas (Doctoral thesis, Faculdade de Ciências Agronômicas da UNESP).

Brachtvogel, E. L., Pereira, F. R. D. S., Cruz, S. C. S., \& Bicudo, S. J. (2009). Maize plant densities in conventional and equidistant plant spacing. Ciência Rural, 39(8), 2334-2339. https://doi.org/10.1590/ S0103-84782009005000193

Braz, G. B. P., Oliveira Jr, R. S. D., Constantin, J., Raimondi, R. T., Ribeiro, L. M., Gemelli, A., \& Takano, H. K. (2016). Weeds as alternative hosts for Pratylenchus brachyurus. Summa Phytopathologica, 42(3), 233-238. https://doi.org/10.1590/0100-5405/2129

Coolen, W. A., \& D'Herde, C. J. (1972). A method for the quantitative extraction of nematodes from plant tissue. Ghent, Belgian: State of Nematology and Entomology Research Station.

Cordeiro, C. F., Kosmann, C. R., Estevez, R. L., Aleixo, V., \& Peters, F. F. (2014). Reprodutividade e parasitismo de Meloidogyne incognita em plantas espontâneas do oeste paranaense. Scientia Agraria Paranaensis, 13(4), 277-282. https://doi.org/10.18188/1983-1471/sap.v13n4p277-282

Dias, W. P., Asmus, G. L., Silva, J. F. V., Garcia, A., \& Carneiro, G. E. S. (2010). In A. M. R. Almeida, \& C. D. S. Seixas (Eds.), Soja: Doenças radiculares e de hastes e inter-relações como manejo do solo e da cultura (pp. 173-206). Embrapa Soja: Londrina.

Embrapa (Empresa Brasileira de Pesquisa Agropecuária). (2013). Tecnologias de produção de soja-Região Central do Brasil (p. 265). Londrina: Embrapa Soja.

Ferraz, L. C. C. B., Pitelli, R. A., \& Soubhia, F. (1982). Nematodes associated with weeds in the Region of Jaboticabal. Planta Daninha, 5(1), 01-05. https://doi.org/10.1590/S0100-83581982000100001

Ferraz, S., Freitas, L. G., Lopes, E. A., \& Dias-Arieira, C. R. (2010). Manejo sustentável de fitonematoides (1st ed.). Viçosa: Editora UFV.

Fuhrmann, E., Braga, M. W., Azevedo, P. H., Gomes, I. A. C., \& Junqueira, N. T. V. (2009). Hospedabilidade de plantas daninhas a Pratylenchus brachyurus na região de Primavera do Leste-MT (pp. 66-67). IV Encontro de Jovens Talentos da Embrapa Cerrados, Brasília-DF. Documentos. Brasília-DF: Embrapa Cerrados.

Goulart, A. M. C. (2008). Aspectos gerais sobre nematoides das lesões radiculares (gênero Pratylenchus). Planaltina, DF: Embrapa Cerrados.

Hillocks, R. J., Stokes, S., \& Jones, M. (1995). Reproduction of Meloidogyne javanica on legume crops and some weed species associated with their cultivation in Malawi. Nematologica, 41(1), 505-515.

Inomoto, M. M. (2011). Avaliação da resistência de 12 híbridos de milho a Pratylenchus brachyurus. Tropical Plant Pathology, 36(5), 308-312.

Inomoto, M. M., Machado, A. C., \& Antedomênico, S. R. (2007). Host status of Brachiaria spp. and Panicum maximum to Pratylenchus brachyurus. Fitopatologia Brasileira, 32(4), 341-344. https://doi.org/10.1590/ S0100-41582007000400009 
Inomoto, M. M., Siqueira, K., \& Machado, A. C. (2011). Crop rotation in center-pivot for phytonematode control: density variation, pathogenicity and crop loss estimation. Tropical Plant Pathology, 36(3), 178-185.

Jordaan, E. M., \& De Waele, D. (1988). Host status of five weed species and their effects on Pratylenchus zeae infestation of maize. Journal of Nematology, 20(4), 620-624.

Lima, J. B., Rios, A. D. F., Rocha, M. R., Machado, A. S., Buso, W. H. D., \& Almeida, E. M. (2016). Reação de Genótipos de Milho a Pratylenchus brachyurus em Condições Naturais de Infestação. ABMS-Associação Brasileira de Milho e Sorgo.

Lordello, R. R. A., Lordello, A. I. L., \& Paulo, E. M. (1988). Multiplicação de Meloidogyne javanica em plantas daninhas. Nematologia Brasileira, 12(1), 84-92.

Mônaco, A. P. A., Carneiro, R. G., Kranz, W. M., Gomes, J. C., Scherer, A., Nakamura, K., Moritz, M. P., \& Santiago, D. C. (2008). Reação de espécies de plantas daninhas a Meloidogyne paranaensis. Nematologia Brasileira, 32(4), 279-283.

Mônaco, A. P. D. A., Carneiro, R. G., Kranz, W. M., Gomes, J. C., Scherer, A., \& Santiago, D. C. (2009). Reação de espécies de plantas daninhas a Meloidogyne incognita raças 1 e 3, a M. javanica e a M. paranaensis. Nematologia Brasileira, 33(3), 235-242.

Oostenbrink, M. (1966). Major characteristics of the relation between nematodes and plants. Mededelingen, 66, $1-46$.

Rios, A. D. F., Rocha, M. R. D., Machado, A. S., Ávila, K. A. G. B., Teixeira, R. A., Santos, L. D. C., \& Rabelo, L. R. S. (2016). Host suitability of soybean and corn genotypes to the root lesion caused by nematode under natural infestation conditions. Ciência Rural, 46(4),580-584. https://doi.org/10.1590/0103-8478cr20150307

Roese, A. D., \& Oliveira, R. D. L. (2004). Capacidade reprodutiva de Meloidogyne paranaensis em espécies de plantas daninhas. Nematologia Brasileira, 28(2), 137-141.

Samaliev, H., \& Kalinova, S. (2013). Host suitability of twelve common weeds to Pratylenchus penetrans and Melodogyne hapla in potato fields of Bulgaria. Bulgaria J. Agric. Sci., 19(3), 202-208.

Stirling, G. R., Halpin, N. V., Dougall, A., \& Bell, M. J. (2010). Status of winter cereals, other rotation crops and common weeds as hosts of lesion nematode (Pratylenchus zeae). Proceedings of the Australian Society of Sugar Cane Technologists, 32, 62-70.

\section{Copyrights}

Copyright for this article is retained by the author(s), with first publication rights granted to the journal.

This is an open-access article distributed under the terms and conditions of the Creative Commons Attribution license (http://creativecommons.org/licenses/by/4.0/). 